Ivan Nikolić ${ }^{1}$

Tatjana Brankov ${ }^{2}$
JEL: M10, D23, L20

DOI:10.5937/industrija46-19286

UDC:005.334.4:338.439.64(497.11)

3

Original Scientific Paper

\title{
Forces Influencing Poor Performance of Serbian Food Industry ${ }^{3}$
}

\author{
Article history: \\ Received: 2 October 2018 \\ Sent for revision: 25 October 2018 \\ Received in revised form: 21 November 2018 \\ Accepted: 21 November 2018 \\ Available online: 28 December 2018
}

\begin{abstract}
The main objective of this paper is to consider the factors that led to the poor performances of the Serbian agribusiness sector in recent years. Moreover, specific objectives are to discuss the productivity trends in agribusiness sector, to evaluate statistical significance of several important determinants like insufficient domestic demand, low product quality, slow technological changes as well as inadequate state support, and to suggest ways to overcome challenges. A methodology used in the analysis and the results can be employed in a number of ways. It should be noted that panel analysis provides a framework for easy interpretation of determinants that affect the performance of agribusiness sector but also serves as a good empirical confirmation of their statistical significance. On the other hand, the results have implications for the food industry and policy decision making process, as they provide evidence on the current and projected economic performance of food manufacturing industry.
\end{abstract}

Keywords: food manufacturing, value added, bulk products, CAP of the EU, random effect model

\section{Uticaji na loše performanse prehrambene industrije Srbije}

Apstrakt: Cilj rada je razmatranje faktora koji generišu loše performanse srpskog agrobiznis sektora poslednjih godina. Pritom, specifični ciljevi analize

\footnotetext{
${ }^{1}$ Economics Institute Belgrade, ivan.nikolic@ecinst.org.rs

${ }^{2}$ University of Novi Sad, Faculty of Economics Subotica

${ }^{3}$ This paper is a part of research project No. 179001 financed by the Ministry of Education, Science and Technological Development of the Republic of Serbia
} 
bili su razmatranje trenda produktivnosti u sektoru agrobiznisa i ocena statističke značajnosti nekoliko bitnih determinanti poput nedovoljne domaće tražnje, niskog kvaliteta, sporih tehnoloških promena te neadekvatne državne podrške, uz predlog mera za prevazilaženje ovih izazova. Rezultati $i$ metodologija koju smo koristili mogu se koristiti na više načina. Naglašavamo da panel analiza pruža okvir za lako tumačenje faktora koji određuju performanse agrobiznis sektora dok su istovremeno i dobra empirijska potvrda njihove statističke značajnosti. S druge strane, rezulati imaju implikacije za prehrambenu industriju i proces donošenja odluka, jer pružaju dokaz o trenutnom i projektovanom učinku prehrambene industrije.

Ključne reči: prehrambena industrija, dodata vrednost, rinfuzna roba, Zajednička poljoprivredna politika EU, model stohastičkih efekata

\section{Introduction}

Historically, as countries grew from low-income, agriculture-based economies to higher income, industrialized economies, manufacturing's relative share of employment and value added increased. Jobs and production moved from primary sectors such as farming into factories and services. However, as economic growth continued, services would generally continue to grow in share while manufacturing would start declining in relative terms. This process, called deindustrialization, usually manifests itself first in employment. As productivity in manufacturing continues to rise, employment in manufacturing starts declining even as share of value added continues to increase. Only later does the share of value added in manufacturing also start declining, as rising incomes support increased domestic demand for services and rising wages lead to production being pushed to lower cost geographies (McKinsey, 2018).

Unfortunately, the Republic of Serbia has not yet reached that stage of development. The agribusiness sector is still very important for the dynamics of Serbian industry - food production employs over half a million people, while the food industry comprises over one fifth of the total manufacturing sector (just over 21\% in 2018), and $19.4 \%$ of total exports (Brankov, 2018). Food production has exceptional multiplier impacts on national economy, too. For example, in US every dollar in value added stimulates further $\$ 4.60$ rounds of spending in the complementary industries, while each employee here was associated with five additional jobs (CED, 2017).

However, over the long term and on average, agribusiness in Serbia is showing a minimum contribution to the growth of the gross added value of the 
country (i.e. gross domestic product), while the food industry itself has been a deductive item for years due to poor financial performance.

As a further confirmation of this hypothesis, we intentionally use 2016 for comparison with previous years, even though it was extremely favourable for agricultural production, yet even this could not contribute significantly to improving the performance of the agribusiness sector. Table 1 clearly shows that the total gross added value in the country is gradually increasing, but food production is stagnant.

Table 1. The average growth of Serbia's real GVA during the observed periods

\begin{tabular}{lrrr}
\hline & $\mathbf{2 0 1 6 / 2 0 0 8}$ & $\mathbf{2 0 1 6 / 2 0 1 1}$ & $\mathbf{2 0 1 6 / 2 0 1 3}$ \\
\hline Production of food products & $-1,7 \%$ & $0,2 \%$ & $-0,4 \%$ \\
\hline Production of beverages & $-27,1 \%$ & $-8,0 \%$ & $-3,2 \%$ \\
\hline Production of tobacco products & $-55,8 \%$ & $-16,4 \%$ & $14,3 \%$ \\
\hline Agribusiness - total & $\mathbf{- 0 , 8 \%}$ & $\mathbf{0 , 5 \%}$ & $\mathbf{- 4 , 2 \%}$ \\
\hline Total economy & $\mathbf{3 , 0} \%$ & $\mathbf{4 , 3} \%$ & $\mathbf{1 , 8 \%}$ \\
\hline
\end{tabular}

Source: Author's calculation; Notes: Time series of GVA by activities are available on the SORS http://data.stat.gov.rs/Home/Result/0902010301?languageCode=en-US

Of particular interest is the finding for the production of foodstuffs during 2016 and in comparison to 2013, where it managed to reduce its gross added value level in the absolute amount by RSD 4.18 billion (value expressed in constant 2010 prices), while simultaneously the economy created new value by RSD 9.32 billion. Consequently, the food industry decreased the real growth of Serbian economy during this period by an incredible $44.9 \%$. As a counter case, we will mention Brazil. In Brazil, for example, the food and beverage industry is one of the fastest growing manufacturing sectors, having expanded output by more than 9 percent annually from 2000 to 2014, while the total number of employees grew by only 2 percent per year in that period (McKinsey, 2018).

Since agriculture registered a roughly double-digit year-on-year decrease in GVA in 2017, we anticipate that the food industry will also be significantly reduced (at the moment of writing this paper official results for 2017 were not available), since its physical scope of activities compared to 2016 was reduced by $0.1 \%$. Note that the food industry is showing a considerable discrepancy between the realized physical scope and newly created value (primarily an indicator of financial performance). Namely, the physical growth of activity in 2016 marked an increase of as much as 6\% compared to 2015, while gross added value has seen only a symbolic $0.3 \%$. The unfavourable trends have also been transferred to 2017 and 2018, too. 


\section{Factors driving developments in the agribusiness sector}

Globally, the agribusiness industry is undergoing a period of considerable change across numerous fronts. From changing consumer food preferences and related shifts toward "clean label" products, to sustained low commodity prices for farmers, to the recent surge in AgTech development and adoption, the agribusiness sector finds itself in the midst of enormous changes and dynamic trends that will continue to shape how food is grown, raised and produced for years to come (Walter\& Herther, 2017; Deloitte, 2017).

In Serbia, the challenges are even more severe. Among numerous forces at play across the agribusiness value chain, we have identified several key trends that are contributing to such poor performance.

Firstly, insufficient demand presents a problem. Strong domestic demand is a key trigger of the dynamics of those areas of the processing industry where economies of scope and the learning curve effects are characteristic. Agribusiness is among these. When the living standard is low, and earnings have been further stagnating in the long-term, or are undergoing a real decrease, however significant the exports may be, agribusiness suffers. For example, the total export of the agribusiness sector of the Republic of Serbia in 2017 reached EUR $2.79 \mathrm{bln}$, and was EUR $1.3 \mathrm{bln}$ higher than imports. Thus we are convinced that the production of food products depends mostly on earning trends. Without their significant growth agribusiness cannot recover.

The relationship between changes in income and the demand for food has been well known by economists. Engel's Law is widely accepted: "the share of a family's income spent for food falls as income rises; that is aggregate food demand in developed countries has an income elasticity between zero and one" (Christy and Connor,1989).

Changing consumer preferences with higher living standards boost food production even further. Recent analyses show that "rising living standards are causing a dietary shift to higher-value-added product, fuelling demand for processed and packaged food and leading to higher equipment sales. An increasing focus on health (organic and healthier food) is driving product/menu expansion and the need for higher standards and traceability, while increased demand for convenient "on-the-go" food presents a growth opportunity for the food service sub-sector" (McKinsey on Food Processing \& Handling, 2018). In doing so, the sector has simultaneously strengthened the coordination with farmers in order to ensure the stable quality needed by consumers. "As consumers seek greater quality, variety, and freshness in food products, these demands must be coordinated along the food value 
chain from farm to consumer (Deloitte Access Economics, 2017). The food industry plays a key role in making sure that the food system meets retailer specifications and consumer demands; for example, it works with producers to make sure that crop varieties have appropriate flavour or processing characteristics, or that meat animals are raised without growth hormones" (CED, 2017).

Knowing this, we believe the announced considerable increase in salaries and pensions from the end of 2018 has been received with great relief in this industry in Serbia.

In addition, we must not forget that demographic change is already affecting the performance of agribusiness, not only through depopulation but also with a decline in the working-age population in some countries. As populations age and birth rates decline, this demographic drag could become stronger and put a greater onus on productivity growth to propel GDP growth (Elias \& Bruggeman, 2017).

Taking into account this fact in Figure 1 domestic demand is expressed on purpose by wages volume.

Figure 1. The dynamics of wages volume and manufacturing of food products in Serbia (period 2015-2017, seasonally adjusted data, average $2016=100$ )

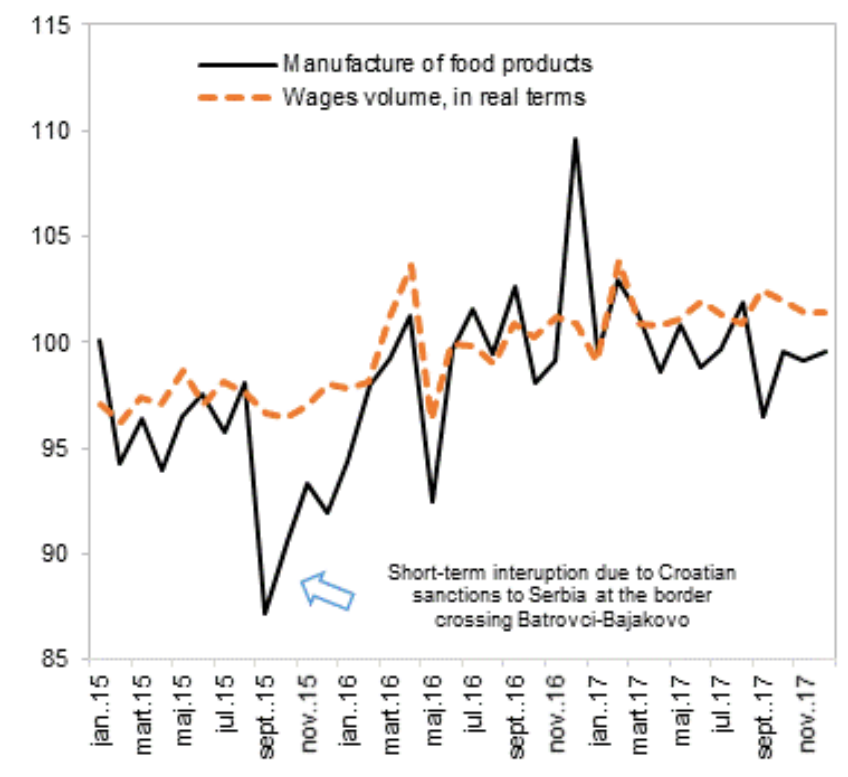

Source: author's calculation; data Statistical Office of the Republic of Serbia, link: http://data.stat.gov.rs/?caller=SDDB 
Figure 2. Share of food and non-alcoholic beverages in the consumption structure, 2018, in per cents*

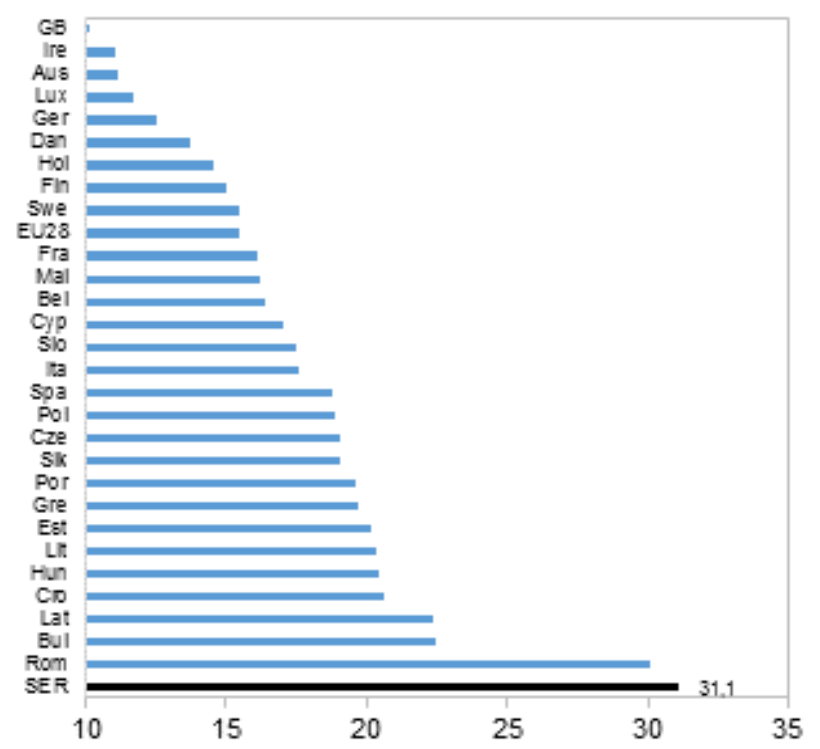

Note: *Food and non-alcoholic beverages weight in Harmonized Consumer Price Index- HICP Source: Authors' calculation based on EUROSTAT data explorer - Title: HICP - item weights

Furthermore, it would seem that exports cannot properly compensate domestic income limitations due to another reason. Namely, it is well known that the main export destination for the food industry is the Western Balkans. Nearly one third of exports are placed on the markets of neighbouring countries that are no better regarding their standard, and where considerable real expansion in this sense in the mid-term is not likely. During 2017 exports to Bosnia and Herzegovina, Montenegro, Macedonia and Croatia were only worth EUR 962 million, representing $34.5 \%$ of the total export value of this sector.

By the way, when considering the potential of demand, it should be noted that it is good when it insists on product refinement. This provides an additional impetus for innovation and differentiation of products, more dynamic growth and competitiveness. In this regard, the expressed desire, for example, of Germans for various types of local beer, the French for numerous types of cheese or Italians for diverse pasta products is welcome, and these three countries are important net exporters of precisely these products.

Another problem is the structure of production. Much like other areas of the Serbian manufacturing sector, agribusiness is dominated by the production of primary products with the lowest technological content. There is no doubt that 
adoption of new technologies within the food industry has been relatively slow. Therefore even the earnings made in exports are low.

A confirmation of this hypothesis can be sought in the share of bulk products in the total export of the agribusiness sector. The share of this segment of agribusiness production in Serbia is traditionally between one fifth and one quarter of the total exports, certainly depending on agricultural yields. On the other hand, EU countries on average register a share of bulk products in the exports of the agribusiness sector of merely around $4 \%$. The most successful food industry countries, such as Germany and Italy, have even lower values; $3.1 \%$ and $2.4 \%$, respectively. Similar relative shares are exhibited by Greece, Spain and the Netherlands.

Figure 3. The share of bulk products* in agribusiness export, 2017

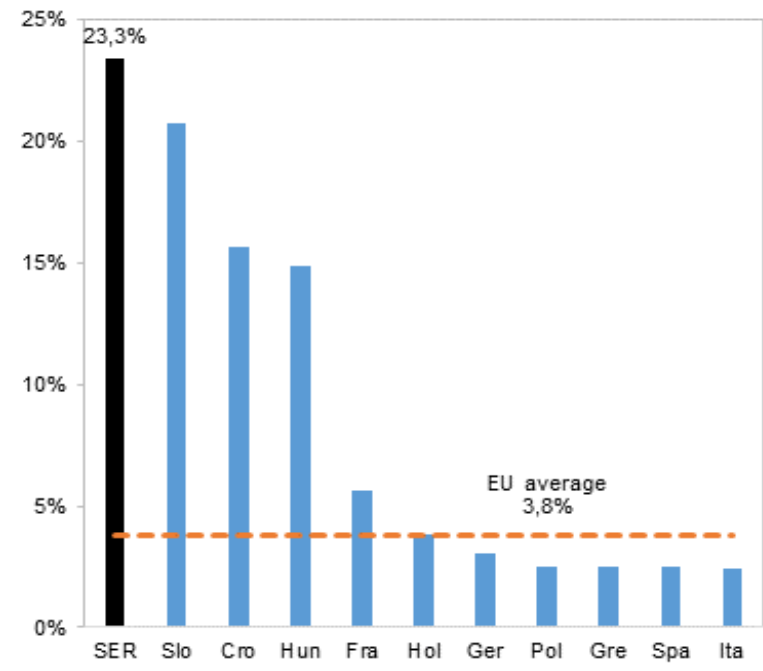

Source: Authors' calculation based on International Trade Centre data (ITC-WTO, UN); Note: *6 dig HS code for bulk agricultural commodities

Unavoidably, there are also considerable issues with difficult product placement. These limitations include all the difficulties with the placement of products on the shelves of large retail chains, starting from the entry, to immediate positioning in them, in the broadest sense. This is a significant challenge for small and medium-sized business in the food sector in the domestic, not to mention in the foreign, competitive food product market in richer industrialized economies. For modern food products, the availability of specialized packaging, transport and logistics companies is crucial especially when perishable goods are delivered to distant export destinations. We know that food products are among the most intensively advertised 
products, and that advertising and marketing campaigns require the financial power that domestic producers do not have.

Figure 4. Unit value of the exports of agribusiness sector in 2017 (EUR/t)

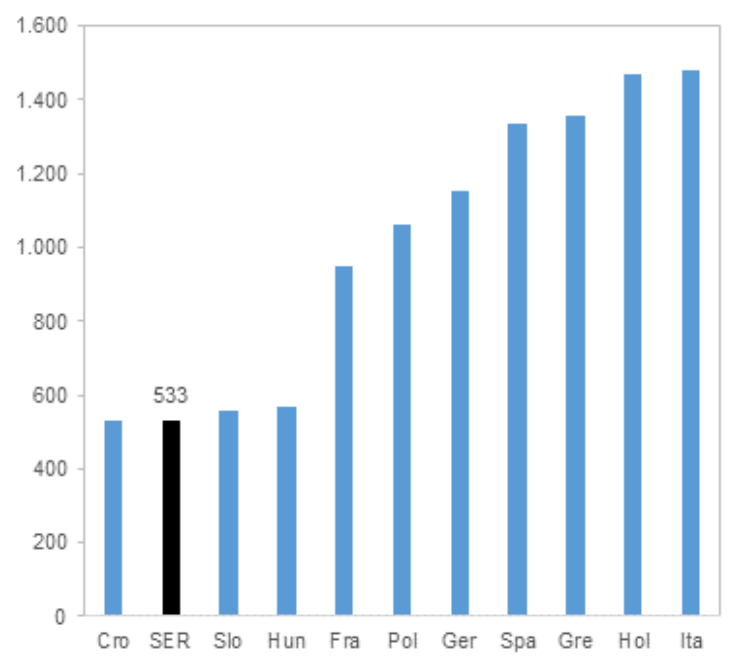

Source: Authors' calculation based on International Trade Centre data (ITC-WTO, UN);

On the other hand, in sales outlets of retail chains in Serbia, there are on average $70 \%$ of domestic production. The rest is made up of imported items. In general, it cannot be said that this is a problem because the necessary competition is promoted. It seems to be far more dangerous that private commercial brands are increasingly "squeezing out" well-known domestic brands. Chains expand the range of products with their signature, which is in the short term good for consumers who are able to buy cheaper groceries. However, the loser is the food industry, first and foremost small and mediumsized producers, who in this case work for large traders with a lower margin, and their products are sold as a trademark.

Insufficient state support should also be listed as an important limitation (Lovre \& Kresoja, 2014). State support to this sector in Serbia is incomparably lower than in EU countries. The role of the state is to strengthen the efficiency of the precisely above mentioned determinants of production by adequate policies, programmes and instruments so that it can retain, or even better, sustainably improve the national competitive advantage. EU countries are champions of this. Particularly in agriculture, they endeavour to affect the competitiveness of local food production through immense financial efforts. Although being a fact, it is also a dilemma whether this generates a more efficient agricultural sector. 
Figure 5. Total GBAORD in agriculture in 2016, EUR per capita

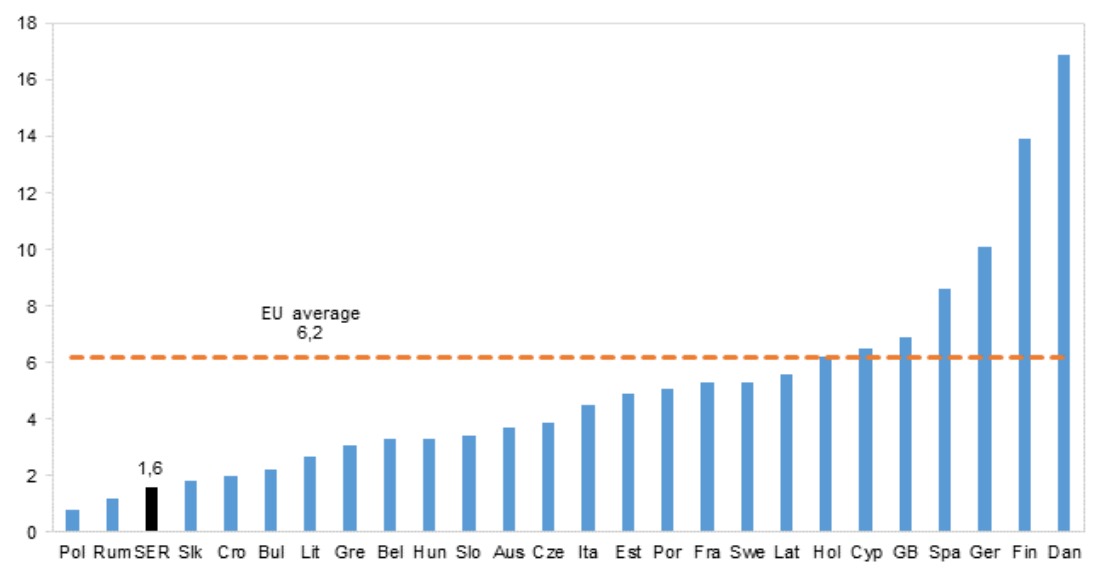

Source: EUROSTAT data explorer - Title: Total GBAORD by NABS 2007 socio-economic objectives [gba_nabsfin07]

Investments into research, development and innovation in agribusiness in the Republic of Serbia during recent years are approximately $0.03 \%$ of GDP, which is, relatively viewed, comparable with European countries. However, in Serbia, due to the large nominal difference in GDP, per capita allocations for these purposes are approximately four times lower than the EU average, while the lag behind the most successful countries in food production is even greater.

Without considerable investments into research, development, and innovation there is clearly no success in any industry, and thus in agribusiness either. Production cannot be modernized by itself, nor can its technological level be increased considerably without state support. It is important to realize that this is not an expense, but an investment in the future, and it would seem that our government recognizes this fact.

Obviously, finding the right set of policies or the appropriate degree of intervention from policy makers for more dynamic agribusiness development has been elusive. After 2000 , school of thought that preferred totally liberal market has prevailed. The belief, often dubbed as the Washington Consensus, maintained that the potential for government failures such as rent capture or inappropriate selection was much larger than for market failures and that governments should let markets run their course to unlock growth, through measures such as liberalizing trade markets and privatization. Performed privatization of companies from the agribusiness complex has faced special criticism in recent years for their inability to create more success cases (Nikolić \& Kovačević, 2014). Indeed, another issue of much public 
interest has been the effect of many mergers and acquisitions in recent years on food manufacturing productivity. On the basis of the measured multifactor productivity index, according to the results of some research, it appears that heightened merger and acquisition activity had little effect on productivity. Some argued that R\&D labs were consolidated and total resources reduced in association with a high number of mergers and acquisitions (Huang, 2003).

\section{Methodology}

For an empirical confirmation of the significance of the considered determinants that affect the performance of agribusiness, we will apply a panel analysis. To measure the productivity of agribusiness sector, firstly we calculate the share of manufacture of food products value added in gross value added of manufacturing industry. Then we analysed a set of South East Europe (SEE) countries, including the Republic of Serbia (for which data on an share of manufacture of food products value added in gross value added of manufacturing industry are available over a period 2012-2015) to see how the data for each observed countries changed over time.

The basic source of data was the Statistical Office of the European Union (EUROSTAT), while for the data analysis we used STATA v.13 statistical package.

Table 2. Observed South East Europe (SEE) countries

\begin{tabular}{c}
\hline Bulgaria \\
\hline Croatia \\
Cyprus \\
Greece \\
Romania \\
Serbia \\
Slovenia \\
\hline
\end{tabular}

Source: authors' calculations

We assessed the equation:

$$
F V A_{i t}=\alpha+x_{i t}^{\prime} \beta+\gamma_{i}+\varepsilon_{i, t} \quad i=1, \ldots, 26 ; \quad t=1, \ldots, 4
$$

where variable FVA is defined as share of manufacture of food products value added in gross value added of manufacturing industry, $i$ is 7 observed countries in SEE, $\alpha$ is constant, $x$ is vector including independent variables (see Table 3 and Table 4), $\beta$ is vector of corresponding coefficients, $t$ is time period, in this case 2012-2015, and $\gamma$ is the effect specific for each country 
and it does not change over time. In our case, these are variables $B U L K$ and $C A P$. Moreover, $\gamma_{i}$ denotes an unobserved time-invariant countries specific effect and $\varepsilon_{i, t}$ represents an error term, which is subject to the assumption of strict exogeneity.

The variables used in the following regression models are defined in Table 2.

Table 3. The variables used in the regression models

\begin{tabular}{|c|c|c|}
\hline Variable & Definition & Source \\
\hline FVA & $\begin{array}{l}\text { The share of manufacture of food products value added } \\
\text { (VA) in gross value added of manufacturing industry, } \\
\text { period 2012-2015 }\end{array}$ & EUROSTAT \\
\hline DEM & $\begin{array}{l}\text { The demand potential as a proxy of nominal household } \\
\text { expenditure for food in EUR corrected with the share of } \\
\text { food in HICP - Harmonised Index of Consumer Prices, } \\
\text { period 2012-2015 }\end{array}$ & EUROSTAT \\
\hline BULK & $\begin{array}{l}\text { The share of bulk agricultural products in agrobusiness } \\
\text { export, in \%, in } 2015\end{array}$ & $\begin{array}{l}\text { International Trade } \\
\text { Centre (ITC-WTO, } \\
\text { UN) }\end{array}$ \\
\hline CAP & $\begin{array}{l}\text { Total CAP (the EU's Common Agricultural Policy) } \\
\text { expenditure, in } 2016 \text { (000 EUR) (EUROSTAT, 2017) }\end{array}$ & EUROSTAT \\
\hline AGRPRO & $\begin{array}{l}\text { Agriculture gross value added, at current prices, million } \\
\text { EUR, period } 2012-2015\end{array}$ & EUROSTAT \\
\hline
\end{tabular}

Source: authors' calculations; Notes: According to 7 USCS $\S 3702$ (Title 7, Agriculture; Chapter 68, Agricultural Subterminal Facilities), the term "bulk agricultural commodity" means "any agricultural commodity that can be transported in bulk and can be temporarily stored in bulk quantities without undergoing processing or packaging. Such term also includes any commodity or product that is used by producers in the production of agricultural commodities and that can be stored or shipped in bulk, such as fertilizer and fuel." see: https://www.law.cornell.edu/cfr/text/31/appendix-B_to_part_560

The expected sign of regression coefficients is in square brackets:

- [+] DEM - is an economic variable representing a potential demand on the market. A lager demand is likely to be associated with more dynamic growth in food production. In some way, it cannot be expected that food production is growing if real salaries stagnate or fall;

- [-] BULK- is proxy for the production of low value added. Surely it follows that higher share of bulk agricultural products in agrobusiness export implies a poor performance of the agribusiness sector i.e. its lagging behind the manufacturing industry;

- [+] CAP - is proxy for the state support to farming sector and rural areas through the CAP. Higher state support should positively affect food production performance; 
- [+] AGRPRO - is the variable of agricultural production in the country. Should have a positive impact because it is certainly a resource base for food production.

Table 4. Panel summary statistics

\begin{tabular}{|c|c|c|c|c|c|c|}
\hline Variable & & Mean & Std. & Min & Max & Observations \\
\hline$t$ & $\begin{array}{l}\text { overall } \\
\text { between } \\
\text { within }\end{array}$ & 2013,5 & $\begin{array}{r}1,1385 \\
0 \\
1,1385\end{array}$ & $\begin{array}{r}2012 \\
103,5 \\
2012\end{array}$ & $\begin{array}{r}2015 \\
2013,5 \\
2015\end{array}$ & $\begin{array}{r}\mathrm{N}=28 \\
\mathrm{n}=7 \\
\mathrm{~T}=4\end{array}$ \\
\hline$F V A$ & $\begin{array}{l}\text { overall } \\
\text { between } \\
\text { within }\end{array}$ & 18,1578 & $\begin{array}{l}8,9632 \\
9,4484 \\
0,9929\end{array}$ & $\begin{array}{r}5,7301 \\
5,8452 \\
15,5689\end{array}$ & $\begin{array}{l}34,9885 \\
33,2144 \\
19,9319\end{array}$ & $\begin{array}{r}\mathrm{N}=28 \\
\mathrm{n}=7 \\
\mathrm{~T}=4\end{array}$ \\
\hline$D E M$ & $\begin{array}{l}\text { overall } \\
\text { between } \\
\text { within }\end{array}$ & 294,7891 & $\begin{array}{l}82,4435 \\
84,4226 \\
21,4862\end{array}$ & $\begin{array}{l}136,1822 \\
157,2587 \\
236,2751\end{array}$ & $\begin{array}{l}413,8016 \\
395,3854 \\
331,9404\end{array}$ & $\begin{array}{r}\mathrm{N}=28 \\
\mathrm{n}=7 \\
\mathrm{~T}=4\end{array}$ \\
\hline BULK & $\begin{array}{l}\text { overall } \\
\text { between } \\
\text { within }\end{array}$ & 14,2578 & $\begin{array}{r}8,8159 \\
9,3507 \\
0\end{array}$ & $\begin{array}{r}2,2979 \\
2,2979 \\
14,2578\end{array}$ & $\begin{array}{l}24,8342 \\
24,8342 \\
14,2578\end{array}$ & $\begin{array}{r}\mathrm{N}=28 \\
\mathrm{n}=7 \\
\mathrm{~T}=4\end{array}$ \\
\hline$C A P$ & $\begin{array}{l}\text { overall } \\
\text { between } \\
\text { within }\end{array}$ & 1245463 & $\begin{array}{r}1343946 \\
1425470 \\
0\end{array}$ & $\begin{array}{r}0 \\
0 \\
1245463\end{array}$ & $\begin{array}{l}3320002 \\
3320002 \\
1245463\end{array}$ & $\begin{array}{r}\mathrm{N}=28 \\
\mathrm{n}=7 \\
\mathrm{~T}=4\end{array}$ \\
\hline AGRPRO & $\begin{array}{l}\text { overall } \\
\text { between } \\
\text { within }\end{array}$ & 2882,664 & $\begin{array}{l}2485,897 \\
2622,558 \\
257,0521\end{array}$ & $\begin{array}{r}321,2 \\
349,925 \\
2156.789\end{array}$ & $\begin{array}{r}7785,2 \\
6957,575 \\
3710,289\end{array}$ & $\begin{array}{r}\mathrm{N}=28 \\
\mathrm{n}=7 \\
\mathrm{~T}=4\end{array}$ \\
\hline
\end{tabular}

Source: authors' calculations

\section{An empirical confirmation of the significance of the considered determinants}

Table 5 demonstrates how the selected variables affect the share of food manufacturing in the total manufacturing GVA. Two-tail p-values test showed that all three variables had a significant influence on the dependent variable. As we hypothesized, variable DEM had a positive impact, whilst variable BULK had a negative impact on the value of the food industry.

The third observed variable, CAP, surprisingly, had a negative effect. However, there are some explanations of this phenomenon.

First and foremost, CAP expenditure within SEE region is not uniform because the Republic of Serbia was taken into consideration, which in the 
observed period did not receive even a cent from the EU budget, and therefore the minimal value of this indicator is zero. Furthermore, the selected countries include the countries that recently joined the EU. It seems that applied policy instruments are not consistent with the challenges faced by new member states. Accession to the EU did not have the same effect on the agri-food sector of the different countries: they are both winners and losers (Csaba and Jambor, 2015). At the same time, there are many arguments for and against the CAP within EU itself (European Commission, 2013).

Table 5. Assessment of impacts of various factors on change of share of manufacture of food products VA in gross VA of manufacturing industry (FVA) in SEE, $2012-2015$ (model 1 - conventional standard errors)

\begin{tabular}{|c|c|c|c|c|c|c|}
\hline \multicolumn{3}{|c|}{ Random-effects GLS regression } & \multicolumn{2}{|c|}{ Number of obs } & $=$ & 28 \\
\hline \multicolumn{3}{|l|}{ Group variable: id } & \multicolumn{2}{|c|}{ Number of groups } & $=$ & 7 \\
\hline \multirow{3}{*}{$\begin{aligned} \text { R-sq: } \text { within } & = \\
\text { between } & = \\
\text { overall } & =\end{aligned}$} & \multicolumn{2}{|l|}{0,2085} & \multicolumn{2}{|c|}{ Obs per group: $\min$} & $=$ & 4 \\
\hline & \multicolumn{2}{|l|}{0,8286} & \multicolumn{2}{|r|}{ avg } & $=$ & 4.0 \\
\hline & \multicolumn{2}{|l|}{0,8210} & & $\max$ & $=$ & 4 \\
\hline & & & & Wald chi2 (3) & $=$ & 23,20 \\
\hline corr $\left(u \_i, X\right)$ & \multicolumn{2}{|l|}{0 (assumed) } & & Prob > chi2 & $=$ & 0,0000 \\
\hline FVA & Coef. & Std.Err. & $z$ & $P>|z|$ & \multicolumn{2}{|c|}{ [95\% Conf. Interval] } \\
\hline$\overline{D E M}$ & 0,0235 & 0,0087 & 2,68 & 0,007 & 0,0063 & 0,0406 \\
\hline BULK & $-0,8335$ & 0,2227 & $-3,74$ & 0,000 & $-1,2699$ & $-0,3971$ \\
\hline CAP & $-3,13 e-06$ & $1,48 e-06$ & $-2,11$ & 0,035 & $-6,03 e-06$ & $-2,18 e-07$ \\
\hline cons & 27,0131 & 5,0293 & 5,37 & 0,000 & 17,1558 & 36,8704 \\
\hline sigma_u & 4,9660 & & & & & \\
\hline sigma_e & 1,0263 & & & & & \\
\hline rho & 0,9590 & (fraction & f varian & due to $\left.u \_i\right)$ & & \\
\hline
\end{tabular}

Source: authors' calculations

Last but not least, the CAP, in the focus, is primarily a characteristics of the sector of agriculture. However, the subject of our analysis is its processing segment, i.e. food industry. Hence, it does not have to mean that there must be a positive interdependence between the CAP and its performance.

The Lagrange Multiplier test (Breusch-Pagan) carried out on the estimates of the random model showed that the random model was appropriate for the data. $p$ value in the test is smaller than $5 \%$ significant level (see Table 6) and this is evidence of significant differences across countries. 
Nikolić I., Brankov T.: Forces Influencing Poor Performance of Serbian Food Industry

Table 6. Breusch and Pagan Lagrangian Multiplier Test for choosing between a random effects regression and a simple OLS regression

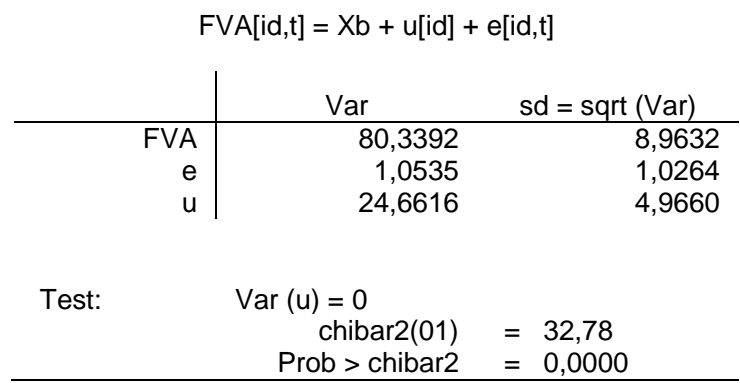

Source: authors' calculations

In addition, we estimate robust standard errors to see if there are any significant differences between conventional standard errors and robust standard errors (Baltagi, Jung, Song, 2010). Our results are robust, i.e. we do not find any significant differences between two sets of standard errors, so we could be confident in our results based on homoskedasticity.

Table 7. Assessment of impacts of various factors on change of share of manufacture of food products VA in gross VA of manufacturing industry (FVA) in SEE, 2012 - 2015 (model 1 - robust standard errors)

\begin{tabular}{|c|c|c|c|c|c|c|}
\hline Random-effects GL & regression & & & Number of obs & $=$ & 28 \\
\hline Group variable: id & & & & umber of groups & $=$ & 7 \\
\hline R-sq: within = & 0,2085 & & $\mathrm{Ob}$ & per group: min & $=$ & 4 \\
\hline between = & 0,8286 & & & avg & $=$ & 4.0 \\
\hline overall = & 0,8210 & & & $\max$ & $=$ & 4 \\
\hline & & & & Wald chi2 (3) & $=$ & 531,02 \\
\hline $\operatorname{corr}\left(u \_i, X\right)$ & 0 (assumed & & & Prob > chi2 & $=$ & 0,0000 \\
\hline & & & & (Std. Err. ad & usted for $7 \mathrm{c}$ & Isters in id) \\
\hline FVA & Coef. & & z & $P>|z|$ & {$[95 \%$ Col } & Interval] \\
\hline & & Std.Err. & & & & \\
\hline DEM & 0,0234 & 0,0099 & 2,37 & 0,018 & 0,0040 & 0,0429 \\
\hline $\begin{array}{l}\text { BULK } \\
\text { CAP } \\
\text { cons } \\
\end{array}$ & $\begin{array}{c}-0,8335 \\
-3.1 .3 e-06 \\
27,0131 \\
\end{array}$ & $\begin{array}{c}0,1713 \\
9.40 e-07 \\
2,6384\end{array}$ & $\begin{array}{r}-4,86 \\
-3.32 \\
10,24 \\
\end{array}$ & $\begin{array}{l}0.000 \\
0.001 \\
0.000\end{array}$ & $\begin{array}{c}-1,1693 \\
-4.97 e-06 \\
21,8420\end{array}$ & $\begin{array}{r}-0,4977 \\
-1,280-06 \\
32,1842\end{array}$ \\
\hline sigma_u & 4,9660 & & & & & \\
\hline sigma_e & 1,0263 & & & & & \\
\hline rho & 0.9590 & (fractic & rerio & due to $u$ & & \\
\hline
\end{tabular}

Source: authors' calculations 
Finally, we added the fourth variable, AGRPRO (variable of agricultural production in the country), to the panel model (Table 8). As hypothesized, AGRPRO had a positive, statistically significant (the $p$-value is less than 0.05 ) impact on the value of the food production. Certainly the food industry is directly dependent on the sector of primary agricultural production and their performances are positively interdependent.

Table 8. Assessment of impacts of various factors on change of share of manufacture of food products VA in gross VA of manufacturing industry (FVA) in SEE, $2012-2015$ (model 2 - robust std.err.)

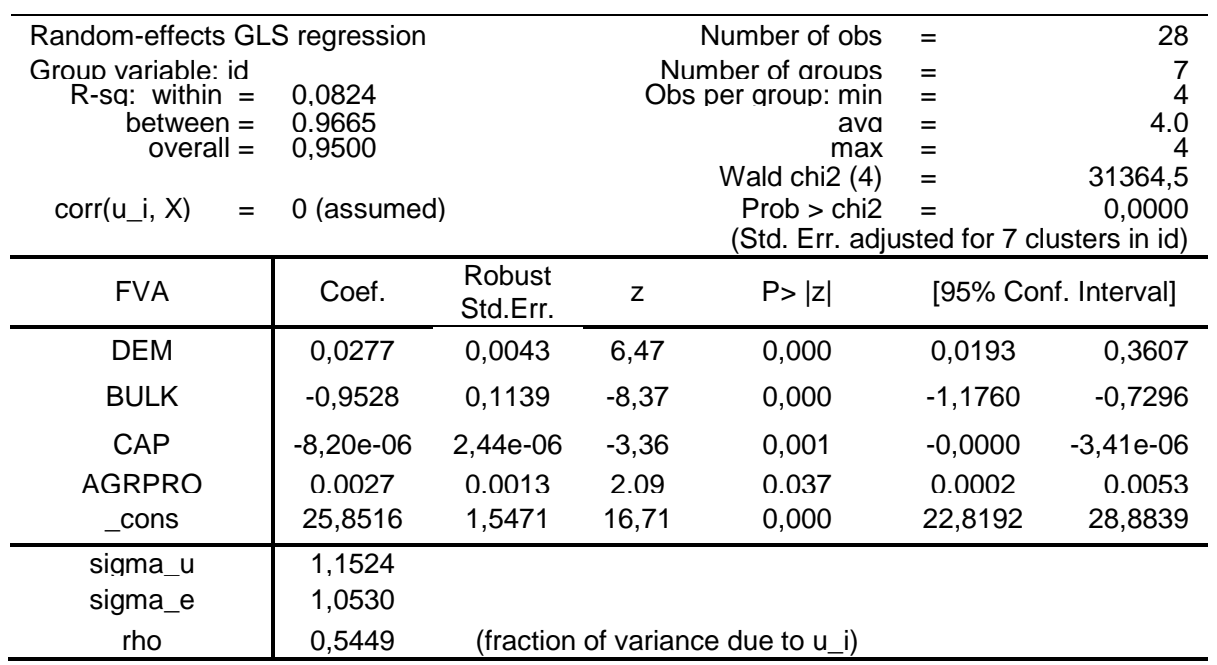

Source: authors' calculations

\section{Concluding Comments}

The main objective of this paper is to consider the factors that led to the poor performances of the agribusiness sector in Serbia. Moreover, specific objectives is to discuss the production trends in agribusiness sector, to evaluate statistical significance of several important determinants of such a result in recent years like insufficient domestic demand, low product quality, slow technological changes, as well as inadequate state support, and to suggest ways to overcome challenges.

A methodology used in the analysis and the results can be employed in many ways. 
It should be noted that panel analysis provides a framework for easy interpretation of determinants that affect the performance of agribusiness sector but also serves as a good empirical confirmation of their statistical significance. With a focus on the fact that food demand is adapting to population change, consumers continue to seek better quality, variety, and services such as additional food preparation and individualized meals for specific nutritional needs, as well assurances about the environmental impacts of food production. Response to these changes requires significant investment by the food industry in research and development, plants and equipment, and consumer outreach.

On the other hand, the results are useful for the food industry and the decision-making process itself. This is also an excellent evidence of the current and projected economic performance of the food sector. We showed that exports cannot properly compensate domestic income limitations because circa one third of exports are placed on the markets of neighbouring countries that are no better regarding the living standard, and where considerable real expansion in this sense in the mid-term is not likely. It only suggests that the government must lead to a more expansive fiscal policy. In this respect, the announced increase in public sector salaries and pensions would be beneficial to agribusiness performance.

\section{References}

-European Commission. (2017). Agriculture and Rural Development: Annual activity report. https://ec.europa.eu/info/publications/annual-activity-report-2017agriculture-and-rural-development_en.

Baltagi, B.H., Jung, B.C., \& Song, S. $\bar{H}$. (2010). Testing for heteroskedasticity and serial correlation in a random effects panel data model. Journal of Econometrics, 154(2), 122-124. doi:10.1016/j.jeconom.2009.04.009

Brankov, T. (2018). Food Policy in the Republic of Serbia. In Reference Module in Food Science. Elsevier BV. doi:10.1016/b978-0-08-100596-5.22394-9

Christy, R.D., \& Connor, J.M. (1989). Economic Forces Influencing Value-Added Food Industries: Implications for Southern Agriculture. Southern Journal of Agricultural Economics, 21(01), 13-22. doi:10.1017/s0081305200000844

-Committee for Economic Development of The Conference Board (CED). (2017). The Economic Contribution of the Food and Beverage Industry. https://www.ced.org/pdf/Economic_Contribution_of_the_Food_and_Beverage_In dustry.pdf.

Csaba, C., \& Jambor, A. (2015). 10 Years of EU Membership: The case of the NMS agri-food sector. In 2015 Conference International Association of Agricultural Economists, August, 8-14, Milan. 
Nikolić I., Brankov T.: Forces Influencing Poor Performance of Serbian Food Industry

-Deloitte Access Economics. (2017). Shaping our slice of heaven: Industries of $\begin{array}{llll}\text { opportunity. } & \text { November } & 2017 . & \text { p. }\end{array}$ https://www2.deloitte.com/content/dam/Deloitte/nz/Documents/Economics/nzdae-industries-of-opportuinity-2017-final.pdf.

Giannakis, E., \& Bruggeman, A. (2015). Economic crisis and regional resilience: Evidence from Greece. Papers in Regional Science, 96(3), 451-476. doi:10.1111/pirs.12206

-EUROSTAT. Data explorer. https://ec.europa.eu/eurostat/data/database.

Huang, K. (2003). Food Manufacturing Productivity and Its Economic Implications. In U. S. Department of Agriculture, Economic Research Service. Technical Bulletin. 1905..

International Trade Centre data (ITC-WTO, UN). https://www.trademap.org/.

Lovre, K., \& Kresoja, M. (2014). Ekonomski odrazi neoliberalne politike cena poljoprivredno-prehrambenih proizvoda u Srbiji. In S. Mitic \& G. Ognjanov (Eds.), Marketing prehrambenih proizvoda. Beograd: Dosije studio.

(2018). McKinsey on Food Processing and Handling.

McKinsey, (2018). Outperformers: High-growth emerging economies and the companies that propel them.

Nikolic, I., \& Kovacevic, M. (2014). The impact of privatization: Empirical analysis and results in Serbian industry. Industrija, 42(1), 63-86. doi:10.5937/industrija424846

-Statistical Office of the Republic of Serbia. . . link: http://data.stat.gov.rs/?caller=SDDB.

-European Commission. The Common Agricultural Policy after 2013. Public debate: Summary Report. https://ec.europa.eu/agriculture/sites/agriculture/files/cap-post2013/debate/report/summary-report_en.pdf.

The, L.I.I.(. Open access to law. https://www.law.cornell.edu/cfr/text/31/appendixB to part_560.

Walter, P., \& Herther, M. (2017). Nine Trends Transforming the Agribusiness Industry. In Executive Insights. L.E.K. Consulting / Executive Insights. Volume XIX, Issue 62. 